\section{LCA (Life Cycle Assessment)}

\section{LCA}

LCA (Life Cycle Assessment) とは, 製品の製造から 廃異までの全ライフサイクルにわたっての環境に対する 負荷 (エネルギー消費, 資源消費, 大気污染物質排出量, 水質污濁物質排出量等）を積算することによって環境に 対するインパクト（影響）を評価しようとする手法であ る.

目的は, (1) 製品が環境に与えるインパクトに関する情 報を消費者に対して提供することによって，商品選択に 影笽を与え，結果として環境負荷の小さな社会の実現を 目指すこと, (2) 企業が自社製品の環境負荷をライフサイ クルで評価することによって製品の改善を行うこと, (3) 政府などが，技術システムや，対象物の優先順位づけの ために用いることなどである.

\section{LCA の手法}

LCA のフレームについては，まだ国際的標準として 確立したものはないが，現在 ISO で議論されているフ レームを用いて解説する (図 1). LCA は, 目的設定, 1 ンベントリー分析, 影響分析, 解釈の 4 つのステップに 分けられる。

(1) 目的設定

目的設定では，適用対象，研究の深さ，主題を設定す

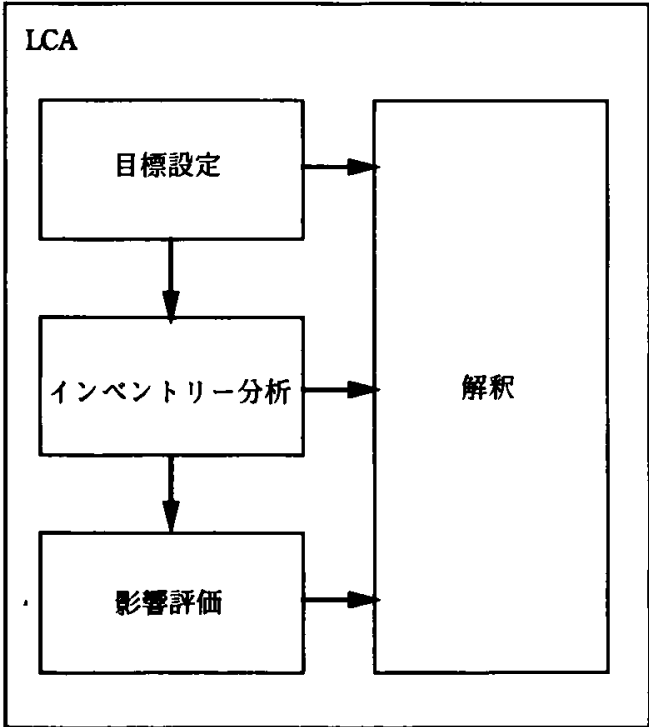

図 1 LCA のフレーム
る.このとき目標となるグループ（消費者，製造者，政 付等）と関係者（研究主体，依頼者等）を明記すること が必要である。

最も重要なことは，機能ユーットの定義である．機能 ユーットとは, 製品が提供する本質的な機能の単位であ る. 例えば，牛乳1リットルの消費等である。

(2)インベントリ一分析

インベントリー分析では，客観的に計算できると考え られている指標について，ライフサイクルにわたって皘 算することが目標となる。

例えば, $\mathrm{CO}_{2}, \mathrm{NOx}, \mathrm{SOx}, \mathrm{COD}, \mathrm{BOD}$, 各種重令属 などの環境污染物質をはじめとし，化石燃料消費，㸚音， 空間利用などがあげられる。

(3) 影響分析

影響分析では，インベントリー表の結果を集約し環境 プロファイル（環境影算指標の表）を作成する．具体的 には $\mathrm{CO}_{2}, \mathrm{NOx}, \mathrm{SOx}$ 加 ら大気污染指標や，温室効果指 標などを計算する.

\section{(4) 解釈}

解釈では，環境プロファイルの評価を行う。環境プロ ファイルは多次元の尺度であるから，全ての尺度での優 劣が一致している場合以外は，互いに矛盾する複数の尺 度を単一の尺度に変換する事が必要となる。

マルチクライテリア分析等によって多次元の尺度を単 一の尺度もしくは，単一の定性的評価軸に集約する。

データの不確実さや, 計算過程の不確実さ, 例えば, 割り付け規則の選択, 重みの変更等の結論に対する影響 を感度分析によって検討する.

\section{LCA の歷史と現状}

LCA の研究は, 1969 年の飲料容器に関する MRI (Midwest Research Institute, 現在 Franklin Associates, Ltd.) の研究に端を発している. 1970 年代前半に は、EPA（アメリカ環境保荄庁）が，REPA (Resource and Environmental Profile Analysis) をまとめた. 80 年代に入って, BUWAL（スイス連邦内務省環境局）が “Eco-Balance of Packaging Materials”を発表した (1984). 1985 年には，ECにおいて，「飲料容器に関する 政令」が発令され，加盟各国の企業は，容器に係わる資 源，エネルギーの利用を監視することが義務付けられ た. 90 年代に入ってからは，ISOにおいて，環境管理国 際規格を検討する TC207 (Technical Committee 207) を設置し（1993），フランスを幹事国として 4，5 年をめ どに LCA の規格化を目指すことを決めた，我が国は， 
インベントリー分析（Inventory analysis）を担当して いる.

この他, OECD, UNEP すワークショップを開催し， LCA に関する研究を進めている.
考文 献

1） LCA-製品の環境ライフサイクルアセスメント， HEIJUNGS, R. (ed.), 戦略 LCA 研究フォーラム訳, サイエンスフォーラム, 1994, 東京.

（東京水産大学水産学部 石川雅紀） 